\title{
Wacana Visual Talk Show 'Mata Najwa': Melihat Bahasa Tubuh Partisipan sebagai Kekuatan Visual
}

\author{
Winny Gunarti W.W., Yasraf Amir Piliang, dan Achmad Syarief \\ Institut Teknologi Bandung (ITB) \\ Jl. Ganesha No. 10 Bandung 40125
}

\begin{abstract}
Ahead of the 2014 election, political and social issues become topics that are often raised on the television talk shows. The existence of a talk show as visual discourse is interesting to study because it can influence public opinion on an issue which involves public figures. In addition to raising the popular issue, the talk show is also designed to perform a professional host and resource person who is in the issue. Mata Najwa talk show on Metro TV is one of the talk shows that features the visual power. By using the studio design as a talk space background, this program focuses on the visual power of Najwa Shihab as the host and resource person appearances where the body of participants become a construction of media to attract the audience's attention. This study discusses one of episodes of 'Mendadak Capres' that presents a public figure Rhoma Irama as resource person. Qualitative analysis with Social Semiotic approach puts participants as part of discourse elements in the production. The focus of discussion include visual signs which consist of facial expressions, hand gestures and body position of the host and the resource person to build their identity and power in the visual discourse of the conversation. The body language of participants becomes important because it can build the audience perception and support atmosphere for discussion. This study can also be a model that the power of a talk show lies not only on the topic, but also on the visual power of the participants through their body language.
\end{abstract}

Keywords: visual discourse, body language, and visual power

\begin{abstract}
ABSTRAK
Menjelang Pemilu 2014, isu sosial politik menjadi topik yang sering diangkat dalam program bincang-bincang (talk show) di televisi. Keberadaan talk show sebagai sebuah wacana visual menarik untuk dikaji karena mampu mempengaruhi opini publik tentang suatu isu yang melibatkan tokoh publik. Selain mengangkat isu populer, tontonan bincang-bincang juga didesain menampilkan pembawa acara profesional serta narasumber yang tengah menjadi isu. Talk show Mata Najwa di Metro TV adalah salah satu tontonan bincang-bincang yang menampilkan kekuatan visual tersebut. Dengan menggunakan latar desain studio sebagai ruang bincang-bincang, kekuatan visual dipusatkan pada penampilan Najwa Shihab selaku pembawa acara dan narasumber di mana tubuh partisipan menjadi bagian dari konstruksi media untuk menarik perhatian penonton. Studi ini membahas salah satu episode 'Mendadak Capres' yang menghadirkan figur publik Rhoma Irama sebagai narasumber. Analisis kualitatif dengan pendekatan Semiotika Sosial menempatkan paritisipan sebagai bagian dari elemen wacana di dalam produksi. Fokus pembahasan meliputi tanda-tanda visual yang terdiri dari ekspresi wajah, gerakan tangan serta posisi tubuh pembawa acara dan narasumber untuk membangun identitas dan kekuasaan di dalam wacana visual perbincangan. Bahasa tubuh partisipan menjadi penting karena dapat membangun persepsi penonton dan mendukung suasana perbincangan. Studi ini sekaligus dapat menjadi sebuah model bahwa kekuatan tontonan bincang-bincang tidak hanya terletak pada topik, tetapi juga pada kekuatan visual partisipan melalui bahasa tubuh.
\end{abstract}

Kata kunci: wacana visual, bahasa tubuh, dan kekuatan visual 


\section{PENDAHULUAN}

Menjelang masa Pemilu 2014, berbagai saluran televisi di Indonesia berlomba-lomba menyajikan berbagai wacana sosial politik dalam bentuk program bincang-bincang (Talk show) bersama para tokoh publik atau politikus. Sebagai salah satu genre tontonan, program Talk show adalah sebuah panggung visual pada layar kaca yang dianggap mampu menarik perhatian penonton; sebuah produk tontonan yang dapat meningkatkan rating televisi; sebuah program informasi yang dipercaya mampu memberikan fakta kebenaran; dan dianggap mampu mempengaruhi persepsi penonton tentang suatu isu ataupun tokoh publik yang terlibat di dalamnya.

Danesi (2009:283) mendefinisikan Talk show sebagai tontonan tempat orang-orang dapat mendiskusikan berbagai aspek kehidupan mereka atau isu-isu terkini dengan dipandu seorang pembawa acara (host). Sedangkan Timberg (2002:2) menyebut program Talk show sebagai sebuah tontonan percakapan tentang sesuatu yang normal, yang tampaknya terlihat spontan, namun sebenarnya secara serius direncanakan dan terstruktur secara format dan praktik. Dengan kata lain, program Talk show adalah salah satu produk tontonan yang dapat dikonstruksi oleh media untuk memenuhi kebutuhan penontonnya.

Program Talk show yang materi penyajiannya merupakan pengembangan dan pertajaman tentang suatu isu yang pernah menjadi bagian dari konten warta berita di jam tayang utama dapat dikategorikan sebagai Talk show berita. Penelitian Timberg (2002) dalam bukunya Talk, A history of The Talk show menguatkan pandangan, bahwa secara format dan model pembawa acara, program Talk show berita berbeda dengan program Talk show hiburan, meskipun Talk show berita itu sendiri dalam praktiknya sudah menjadi hiburan. Perbedaan utama di antara kedua- nya antara lain meliputi topik yang dibincangkan, dan juga peran pembawa acaranya. Beberapa Talk show berita menggunakan pembawa acara yang juga seorang presenter atau penyaji berita. Talk show hiburan umumnya menampilkan pembawa acara dari kalangan figur publik populer.

Konstruksi media terhadap program Talk show berita menjadi penting, karena tontonan ini didesain untuk memproduksi realitas dalam bentuk wacana. Talk show berita didesain dengan menghadirkan elemenelemen esensial di dalam wacana, berupa percakapan atau diskusi antara pembawa acara dan narasumber melalui bahasa visual verbal dan nonverbal, untuk menyajikan informasi atau pengetahuan, dan melibatkan relasi sosial dengan penontonnya.

Dalam perspektif budaya visual, desain sebuah program pada dasarnya bertujuan agar media televisi dapat memenuhi kebutuhan konsumen untuk mendapatkan informasi, makna, atau kesenangan melalui tatap muka dengan teknologi visual (Mirzoeff, 1999:5). Teknologi visual menyaratkan setiap program untuk dirancang dengan kekuatan-kekuatan visual agar dapat menarik perhatian publik.

Akan tetapi, perlu diketahui bahwa kekuatan visual sebuah program Talk show berita tidak hanya terletak pada visual teks verbal, melainkan juga pada visual teks nonverbal. Anggapan bahwa tanpa topik yang menarik, sebuah program Talk show berita menjadi tidak menarik tidak sepenuhnya dapat dibenarkan. Kekuatan visual verbal dalam tayangan Talk show juga sangat tergantung pada kekuatan visual nonverbal yang mendukungnya, yaitu peran dan penampilan pembawa acara serta narasumbernya.

Penelitian yang dilakukan oleh Wardani, Piliang, dan Syarief (2013) sebelumnya terhadap penonton mahasiswa tentang tayangan Talk show berita bertema politik di televisi menunjukkan pentingnya peran pembawa acara selaku penyaji berita atau 
informasi. Dari 100 responden yang mengisi kuesioner, 68 responden menyatakan bahwa pembawa acara yang komunikatif adalah elemen visual yang penting untuk membuat perbincangan atau Talk show berita menjadi menarik perhatian. Dalam penelitian Casey \& Casey, Clavert, French \& Lewis (2001:279) juga menunjukkan bahwa pusat strategi komunikasi dalam sebuah program wawancara berada pada percakapan terbuka yang dibawakan oleh pembawa acara, sehingga kekuatan visual program sangat tergantung pada peran penampilan pembawa acara sebagai citra visual dari teks verbal dan nonverbal, selain tampilan desain ruang di dalam ruang visual yang mendukungnya sebagai teks nonverbal.

Selama tayangan Talk show berlangsung, interaksi yang terjadi antara pembawa acara dengan narasumber menyajikan aspek visual nonverbal lainnya, yaitu pesan yang disampaikan oleh keduanya sebagai partisipan melalui bahasa tubuh. Dalam konteks program Talk show sebagai wacana visual, bahasa tubuh yang ditampilkan oleh pembawa acara dan narasumber menjadi tanda-tanda visual yang bermakna. Selama berdiskusi, baik pembawa acara maupun narasumber secara visual nonverbal masing-masing berupaya menunjukkan eksistensinya di dalam layar untuk menyajikan perbincangan yang menarik dengan memberikan identitas-identitas tertentu melalui ekspresi wajah, gerakan tangan, maupun posisi tubuh, sehingga secara tidak langsung terjadi pembentukan identitas dan kekuasaan di dalam wacana perbincangan. Identitas adalah ciri-ciri atau personalitas yang ditampilkan seorang individu. Sedangkan makna kekuasaan sebagaimana dituliskan Foucault (dalam Danaher, Schirato, and Webb, 2000: xiv) adalah: "Power produces resistance to itself; it produces what we are and what we can do; and it produces how we see ourselves and the world."

Pernyataan Foucault dalam konteks program Talk show menunjukkan bahwa bahasa tubuh yang mengidentifikasikan kekuasaan dapat merepresentasikan citra pembawa acara serta narasumber. Berdasarkan persoalan tersebut, studi ini merumuskan pertanyaan: Bagaimana visualisasi dari bahasa tubuh ini dipresentasikan sebagai kekuatan visual melalui pembawa acara dan narasumber, sehingga merepresentasikan identitas dan kekuasaan partisipan di dalam wacana perbincangan?

Kajian wacana visual dalam studi ini mencoba menemukan makna dari penggunaan bahasa visual nonverbal, khususnya bahasa tubuh partisipan di dalam sebuah program Talk show berita sebagai teks visual. Fungsi penggunaan bahasa itu sendiri menurut Halliday (dalam van Leeuwen, 2005:76) mampu menciptakan tidak hanya fungsi interaksinya sebagai bentuk ekspresi, tetapi juga di antaranya fungsi imajinatif untuk mencitrakan sesuatu, dan fungsi informasi sebagai pembawa pesan tertentu. Selain itu, studi ini diharapkan dapat menjadi bentuk model tayangan yang mampu menunjukkan kekuatan visual melalui pemaknaan bahasa tubuh partisipan sebagai pendukung daya tarik visual program Talk show.

\section{Objek Kajian sebagai Model}

Studi ini memilih salah satu program Talk show yang ditayangkan TV swasta nasional, yaitu program Talk show 'mata najwa' dari Metro TV. Objek kajian dipilih secara purposive dari salah satu episode Talk show 'mata najwa' di rentang waktu tahun 2012 hingga awal tahun 2013. Di rentang tahun tersebut Talk show 'mata najwa' beberapa kali menampilkan tokoh-tokoh publik yang mencalonkan diri sebagai Presiden di Pemilu tahun 2014. Salah satunya adalah episode 'Mendadak Capres' yang menampilkan tokoh publik Rhoma Irama sebagai kandidat Presiden. Perbincangan antara pembawa 


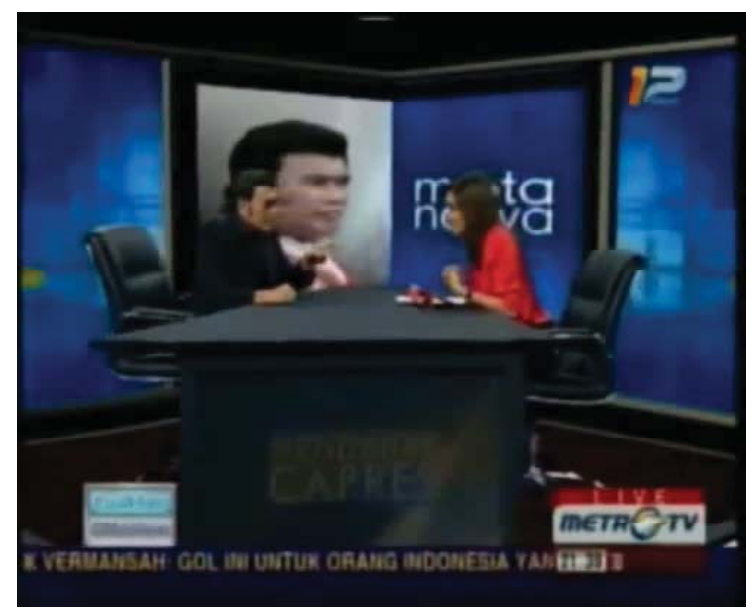

Gambar 1

Talk show 'mata najwa' Episode 'Mendadak Capres'

Sumber: Daniel As-Huri, 2 Desember 2012, "mata najwa"-Rhoma Irama Mendadak Capres, http:// www.youtube.com/watch?v=PCwHdPRll8Q, diakses 5 November 2013.

acara Najwa Shihab dengan narasumber yang tengah menimbulkan pro dan kontra di masyarakat tersebut menjadikan tayangan Talk show ini cukup menarik perhatian penonton dan banyak mendapat ulasan di dunia maya seusai penayangannya.

Pemilihan terhadap objek kajian juga didasarkan pada pertimbangan hal-hal berikut, yaitu: Metro TV adalah salah satu TV swasta nasional yang memfokuskan seluruh programnya berbasis berita dan memiliki sebelas program Talk show dengan tiga di antaranya berjenis Talk show berita (http:// www.metrotvnews.com/, diakses 15 Februari 2014); Program Talk show berita 'mata najwa' dibawakan oleh Najwa Shihab yang namanya cukup populer di masyarakat sebagai jurnalis profesional, presenter dan penyaji berita; Citra Najwa Shihab sebagai elemen visual di dalam program memiliki nilai kompetitif dalam perannya sebagai pembawa acara dengan pengalaman jurnalistiknya; Program Talk show berita 'mata najwa' berhasil masuk nominasi dalam Asian Television Awards 2010 sebagai Talk show Terbaik Se-Asia Pasifik; Pada tahun 2013, Talk show berita 'mata najwa' juga berhasil me- menangkan Anugerah KPI 2013; Program Talk show berita 'mata najwa' termasuk program yang cukup bertahan lama, pertama kali ditayangkan Metro TV pada tanggal 25 November 2009 dan hingga saat ini masih terus ditayangkan; Program ini menggunakan nama pembawa acaranya sebagai salah satu ciri kekuatan visual teksnya; Jenis program Talk show berita dengan pembawa acara perempuan yang juga presenter berita dan memakai namanya sebagai nama program termasuk sedikit di dalam dinamika program Talk show berita di Indonesia.

Program Talk show 'mata najwa' ditayangkan setiap hari Rabu malam pukul 21.30-22.30. Format acaranya didesain sebagai dokumentasi berita dengan misi informasi yang fokus, tajam, kritis, investigatif, berdasarkan kilas balik peristiwa dalam format softnews, yaitu bentuk wawancara yang menggali fakta dari peristiwa yang pernah terjadi atau terdokumentasikan, bersifat personal dengan narasumber untuk mendalami peristiwa, mengungkap fakta tersembunyi, menjaring informasi langsung dari narasumber utama dalam sudut pandang human interest (http:// www.metrotvnews.com/read/anchor, diakses 15 Februari 2014).

Progam ini umumnya menghadirkan narasumber tokoh-tokoh nasional yang sedang menjadi isu di masyarakat. Para narasumber yang ditampilkan dalam Talk show 'mata najwa' ini umumnya dipilih dari kalangan pengamat, wakil pemerintah, dan wakil lembaga masyarakat. Para narasumber dipilih sebagai tokoh-tokoh publik yang dianggap dapat mewakili kepentingan masyarakat.

\section{Pendekatan dan Metode}

Talk show 'mata najwa' sebagai produk tontonan, adalah sebuah pertunjukan wacana tempat para partisipan berdiskusi, menyajikan pengetahuan dan saling me- 
nampilkan karakteristik bahasa visual nonverbal yang spesifik.

Foucault (dalam Danaher, Schirato, and Webb, 2000: x) menyatakan wacana digunakan untuk menggambarkan tindakan bahasa individual, atau 'bahasa di dalam tindakan', suatu gagasan dan pernyataan yang memungkinkan kita untuk mengartikan dari dan 'melihat' hal-hal lain. Wacana dalam pandangan Foucault adalah cara mengkonstruksi pengetahuan, praktik sosial yang menyertainya, bentuk subjektivitas yang dihasilkannya, serta relasi kekuasaan yang ada di baliknya. Pandangan Foucault tersebut mendasari pemikiran bahwa program Talk show 'mata najwa' dianggap dapat menghidupkan makna wacana melalui pertukaran bahasa visual verbal dan nonverbal, khususnya melalui bahasa tubuh.

Dalam memaknai bahasa tubuh partisipan berarti menemukan makna pada bahasa visual nonverbal. Menurut Fiske (2007:94-95), komunikasi nonverbal dapat berlangsung melalui kode-kode presentasional seperti gestur, postur, atau sifat suara, tapi dapat juga ditampilkan dengan kode representasional, sejauh kode presentasional tersebut dapat disajikan dalam pesanpesan representasional, yaitu suatu proses penyampaian informasi atau gagasan, dengan melibatkan penciptaan pesan atau teks yang terlepas dari komunikator dan situasi. Hal ini juga dapat mengacu pada sudut pandang konstruksionis menurut Hall (1997 dalam Burton, 2011:249) yaitu pandangan yang tergantung pada penggunaan kodekode visual, kode teknis, kode busana, dan sebagainya, yang ditampilkan di layar televisi.

Pembacaan tanda melalui bahasa tubuh di dalam konteks wacana visual dapat ditelaah dengan melihat salah satu dimensi, yaitu dimensi teks bahasa (language text) dari model hubungan tiga dimensi dari Analisis Wacana Kritis (Critical Discourse Analysis [CDA]) Norman Fairclough (2006:73).

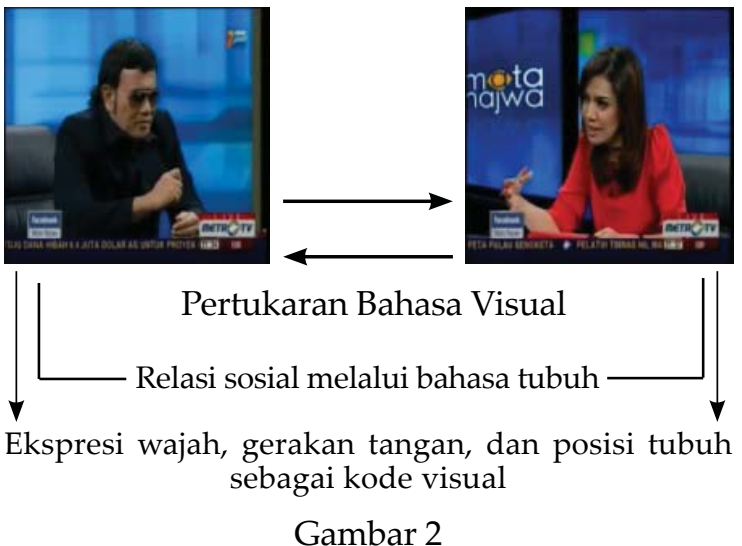

Bagan Bahasa Visual di Dalam Wacana

Dimensi teks bahasa di sini merupakan dimensi bahasa visual nonverbal yang menunjukkan bahwa penampilan objek tidak hanya digambarkan tetapi juga bagaimana hubungan antar-objek didefinisikan melalui representasi, relasi, dan identitas dari partisipan di dalam wacana. Analisis wacana dapat menunjukkan bagaimana bahasa visual nonverbal sebagai teks visual melalui bahasa tubuh dapat pula digunakan untuk menyampaikan pesan.

Birdwhistell (dalam Littlejohn, 1996:87) menyebut bahasa tubuh (body language) sebagai sebuah studi kinesik, tempat terjadinya relasi antara bahasa tubuh dengan bahasa yang diucapkan secara verbal, sehingga bahasa tubuh juga mampu membawa makna. Adapun Abne Eisenberg dan Ralph Smith (dalam Littlejohn, 1996:87-89) menyebutkan bentuk-bentuk komunikasi nonverbal yang dapat disampaikan melalui visualisasi aktivitas manusia dalam bentuk presentasi fasial, yaitu baik ekspresi wajah maupun presentasi postural berupa gerakan anggota tubuh, khususnya tangan yang dapat dikategorikan sebagai bagian dari gesture.

\section{Presentasi Fasial}

Presentasi fasial merupakan aktivitas bahasa tubuh yang berada di area wajah. Analisis tanda mengacu pada ekspresi wa- 


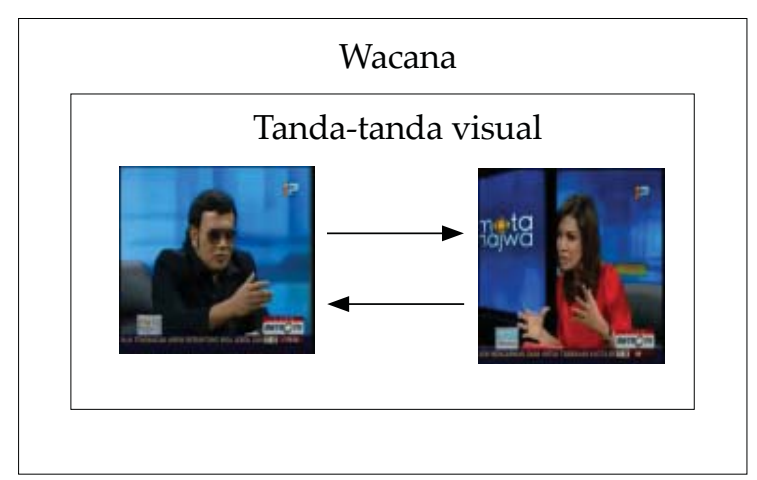

Gambar 3

Produksi Teks Bahasa Visual Nonverbal sebagai Tanda-Tanda Visual

jah partisipan. Dalam raut wajah, penampilan pembawa acara dan narasumber dapat digambarkan dengan berbagai ekspresi. Menurut Cohen (2009:41) wajah manusia dikenal memiliki enam ekspresi emosional dasar, yaitu ekspresi gembira, sedih, merasa jijik, takut, marah, dan heran. Keenam ekspresi ini biasanya muncul saat berinteraksi dengan orang lain.

Dalam konteks perbincangan, presentasi fasial juga dapat ditunjukkan melalui orientasi wajah partisipan, terutama arah pandangan dan cara menatap. Dikatakan Cohen (2009: 55), cara manusia menatap orang lain cenderung diatur oleh kebudayaan di mana manusia itu berada. Terutama dalam hal kontak mata, ada norma sosial yang mengaturnya. Dalam kebudayaan barat, tatapan atau kontak mata yang terlalu sedikit dianggap menunjukkan pribadi yang cenderung berubah-ubah, sedangkan bila tatapan atau kontak mata terlalu lama dianggap mendominasi. Apabila dalam berkomunikasi dengan orang lain, tatapan atau kontak mata kedua belah pihak saling bertemu selama sekitar $60-70 \%$, dapat dimaknai menunjukkan minat terhadap sesuatu. Adapun jika pertemuan kontak mata hanya berlangsung sekitar 30\% dapat dimaknai sebagai menyembunyikan sesuatu. Tatapan yang mendominasi berpotensi menempatkan seseorang atau sesuatu yang ingin diklaim.

\section{Presentasi Postural}

Presentasi postural merupakan tandatanda yang ditampilkan melalui gerakan dan posisi tubuh. Pesan postural berkenaan dengan keseluruhan anggota badan (Rakhmat, 2008:290). Namun, presentasi postural di sini hanya dibatasi pada aktivitas bagian tubuh saja, yaitu gerakan tangan dan perilaku khas. Gaya gerakan tangan dapat dikatakan sebagai gesture, yaitu gerakan tubuh khususnya tangan untuk mengkomunikasikan sesuatu secara sadar maupun tidak sadar (Danesi, 2009:133). Gesture seseorang dapat menjadi perilaku khas sebagai identitas diri. Setiap individu, secara sadar atau tidak sadar, umumnya memiliki perilaku yang khas pada saat berkomunikasi dengan orang lain. Perilaku khas dianggap sebagai perilaku kompensasi untuk mengendalikan diri atau dapat dianggap pula sebagai bagian dari gaya individu yang menjadi daya tarik pribadi.

Bentuk-bentuk dasar gestural afektif yang secara umum digunakan dalam berkomunikasi, yaitu (Wundt, 1973:73):

1. Demonstrative gesture

Suatu gerakan tangan untuk mengekspresikan emosi. Ini bentuk gesture yang dapat memiliki arti berbeda dan dapat diartikan secara luas, sesuai dengan lingkungan masyarakat maupun kebiasaan setempat. Misalnya untuk mengkomunikasikan kata 'merah' kepada seseorang, cukup dengan menunjuk bibir.

\section{Imitative gesture}

Suatu gerakan tangan untuk menirukan atau menggambarkan keadaan. Misalnya gerakan dua jari berjalan untuk menunjukkan keadaan sedang atau ingin berjalan.

\section{Connotative gesture}

Suatu gerakan tangan untuk mengkomunikasikan citra tertentu menurut asosiasi yang berlaku. Bentuk gesture ini juga dapat dimaknai berbeda-beda. Konotasi gestural dapat dikoneksikan antara tangan dengan 
wajah untuk mengekspresikan perasaan dan pikiran. Misalnya gerakan tangan memegang dagu, bibir, atau gerakan tangan menunjuk. 4. Symbolic gesture

Suatugerakan tangan yang mengkomunikasikan suatu konsep mental, menggabungkan antara tanda dan nilai-nilai simbolis. Maknanya dapat bersifat ambigu dan hanya dapat dipahami melalui relasi pikiran.

Mengenai posisi Tubuh, menurut Cohen (2009: 47) adalah cara seseorang memposisikan tubuh terhadap orang lain sebagai kunci untuk menyambut atau mempertahankan diri. Posisi tubuh dapat dilihat dari cara duduk.

Asosiasi makna bahasa tubuh berkaitan erat dengan pembacaan tanda-tanda visual menurut fungsi Semiotika Sosial. Akan tetapi, analisis studi tanda di dalam konteks wacana visual tempat produksi teks visual nonverbal berada tidak melibatkan penonton, sebaliknya lebih memfokuskan pada tanda-tanda visual yang ditampilkan pembawa acara dan narasumber. Secara kualitatif, pendekatan Semiotika Sosial menjadi alat untuk mendeskripsikan, sekaligus menganalisis elemen-elemen visual sebagai bentuk kode presentasional, seperti gesture dan postur.

Mengacu pada istilah dari Michael Halliday tentang fungsi di dalam struktur sintaktik dan fungsi di dalam masyarakat atau penggunaan bahasa, van Leeuwen (2005: 75-76) kemudian menerapkannya dalam tata fungsional sistem desain visual yang di antaranya menjabarkan fungsi interaktif, fungsi personal, fungsi imajinatif, dan fungsi informatif dari aktor-aktor yang terlibat di dalam tayangan visual.

Dikatakan pula oleh Krees dan van Leeuwen (2006:115-177), interaksi yang terjadi antara partisipan dapat dibedakan menjadi dua jenis partisipan, yaitu: represented participants (orang, tempat, dan benda-benda yang ditampilkan dalam gambar), dan interactive participants (orang-orang yang berkomuni-

\begin{tabular}{|ll|}
\hline Presentasi & Bahasa Tubuh \\
\hline \multirow{2}{*}{ Fasial } & Ekspresi wajah \\
& Orientasi wajah \\
& melalui arah tatapan \\
Postural & Gerakan tangan \\
& Perilaku khas \\
& Posisi tubuh \\
\hline
\end{tabular}

Tabel 1

Presentasi Fasial dan Postural

kasi satu sama lain melalui gambar, termasuk di dalamnya interaksi dengan produser dan penonton).

Akan tetapi dalam pembahasan studi ini, pembacaan bahasa tubuh dimaknai hanya dalam konteks orang, tempat dan bendabenda yang ditampilkan, yang elemen-elemen visualnya dapat dijabarkan menurut makna representasi, yaitu makna representasional yang dihasilkan melalui presentasi bahasa tubuh partisipan dalam representasi gambar, makna interaksi/interaktif, yaitu makna interaksi melalui presentasi bahasa tubuh antara pembawa acara dan narasumber sebagai orang-orang yang berkomunikasi satu dengan lainnya melalui gambar, dan makna komposisi yang menghubungkan makna representasional dan makna interaksi gambar dengan gambar lainnya, sebagai nilai informasi, melalui penempatan elemenelemen visual pendukung di dalam zona pengambilan gambar.

Selain itu, makna terhadap penampilan pembawa acara dan narasumber menurut realitas media juga dapat menggunakan pendekatan budaya selebritas, yaitu menempatkan partisipan sebagaifiguryang berpotensi menjadi figur publik melalui representasi identitas dan kekuasaan yang ditampilkannya.

Dalam budaya selebritas, seseorang yang tampil di televisi dapat menjadi 'berita' atas dasar apa yang ditampilkannya. Dikatakan Lawrence (2009:12), ketika masyarakat penonton telah menempatkan seseorang sebagai selebritas, maka masyara- 
kat memberikan perhatian secara khusus dan memandangnya sebagai seorang ahli di dalam segala bidang, mulai dari fesyen hingga pada pandangan-pandangan politiknya. Dengan pendekatan budaya selebritas, penampilan partisipan di dalam program Talk show secara tidak langsung juga dapat membangun persepsi di masyarakat tentang citra identitasnya.

Oleh karena itu, pembacaan bahasa tubuh tidak dapat dilepaskan dari penandaan melalui sudut pandang kamera dan pergerakannya. Dalam Semiotika televisi, identitas partisipan juga dapat dibangun melalui pengambilan gambar oleh kamera untuk menghadirkan karakter dan daya tarik pribadi individu itu sendiri melalui penampilan bahasa tubuhnya. Bahasa tubuh partisipan dapat mewujudkan makna penanda dan petanda ketika posisi partisipan ditempatkan sebagai subjek visual dalam realitas media, sebagaimana dijabarkan dalam tabel 2.

Adapun menurut Block (2008:30), terdapat tiga gerakan kamera yang dapat membangun imaji terhadap visualisasi bahasa tubuh partisipan, yaitu: gerakan mendekat atau menjauh, gerakan ke kanan atau ke kiri, dan gerakan ke atas atau ke bawah. Beberapa jenis pergerakan sudut pandang kamera yang umumnya dilakukan dalam penayangan program Talk show adalah jarak dekat (Close-up) untuk memvisualisasikan wajah partisipan dalam jarak dekat. Kemudian jarak sedang (Medium shot) untuk mem-

\begin{tabular}{|lll|}
\hline $\begin{array}{l}\text { Penanda } \\
\text { (Signifier) }\end{array}$ & Definisi & $\begin{array}{l}\text { Petanda } \\
\text { (Signified) }\end{array}$ \\
\hline $\begin{array}{l}\text { Close-up } \\
\text { Medium shot }\end{array}$ & $\begin{array}{l}\text { Hanya wajah } \\
\text { Kebanyakan tubuh }\end{array}$ & $\begin{array}{l}\text { Keintiman } \\
\text { Hubungan } \\
\text { personal }\end{array}$ \\
Full shot & Seluruh tubuh & $\begin{array}{l}\text { Hubungan } \\
\text { sosial }\end{array}$ \\
Long shot & Latar dan & $\begin{array}{l}\text { Konteks, } \\
\text { wilayah, } \\
\text { jarak publik }\end{array}$ \\
& karakter & arak \\
\hline
\end{tabular}

Tabel 2

Definisi Sudut Pandang Kamera dalam Semiotika Televisi (Adler, Ed., 1981:110)

\begin{tabular}{|c|c|}
\hline Pergerakan Kamera & Visualisasi \\
\hline $\begin{array}{l}\text { Jarak dekat (Close-up) } \\
\text { Jarak sedang (Medium shot) } \\
\text { Jarak penuh (Full shot) }\end{array}$ & $\begin{array}{l}\text { Wajah pembawa acara } \\
\text { dan narasumber } \\
\text { Bagian tubuh (tidak } \\
\text { penuh) partisipan } \\
\text { Seluruh tubuh partisi- } \\
\text { pan dan sebagian latar } \\
\text { ruang } \\
\text { Latar tampilan ruang } \\
\text { secara keseluruhan }\end{array}$ \\
\hline
\end{tabular}

Tabel 3

Pergerakan Kamera

(diadaptasi dari Adler, Ed.,1981: 110)

visualisasikan tubuh partisipan setengah bagian. Lalu ada pergerakan kamera jarak penuh (Full shot) untuk memvisualisasikan seluruh tubuh partisipan berikut menggambarkan latar. Dan pergerakan kamera jarak jauh (Long shot) untuk menampilkan seluruh desain latar dan tampilan partisipan secara menyeluruh.

Tanda-tanda visual melalui bahasa tubuh partisipan yang menjadi kekuatan visual untuk mendukung jalannya susasana perbincangan di dalam Talk show 'mata najwa' juga menyertakan unsur-unsur penandaan dari pergerakan kamera tersebut. Keseluruhan elemen visual menjadi sebuah kesatuan tanda yang dapat dimaknai menurut konteks kode presentasi dan representasinya. Pembahasan tentang kekuatan visual bahasa tubuh melalui elemen tanda ekspresi wajah, gerakan tangan, dan posisi tubuh hingga membentuk makna identitas dan kekuasaan partisipan dapat dijabarkan pada sub judul selanjutnya.

\section{PEMBAHASAN}

Program Talk show 'mata najwa' didesain untuk menjadi sebuah tontonan perbincangan yang memiliki kekuatan khusus, terutama kekuatan yang dimiliki oleh pembawa acara dalam membawakan topik perbincangan. Najwa Shihab selaku produser dan pembawa acara memiliki kekuasaan untuk meng- 


\begin{tabular}{|c|c|c|}
\hline Partisipan & Identitas & Kekuasaan \\
\hline Najwa Shihab & Pembawa acara & $\begin{array}{l}\text { Produser pro- } \\
\text { gram Talk show } \\
\text { 'mata najwa'. } \\
\text { Mewakili kepen- } \\
\text { tingan media a- } \\
\text { tau pemilik mo- } \\
\text { dal. } \\
\text { Investigator atau } \\
\text { menggali infor- } \\
\text { masi. } \\
\text { Menyajikan fak- } \\
\text { ta kebenaran. } \\
\text { Mewakili kepen- } \\
\text { tingan masyarakat }\end{array}$ \\
\hline Rhoma Irama & Terwawancara & $\begin{array}{l}\text { Bintang tamu } \\
\text { program Talk } \\
\text { show'mata najwa' } \\
\text { Mewakili kepen- } \\
\text { tingan kelompok } \\
\text { masyarakat ter- } \\
\text { tentu. } \\
\text { Memberikan ja- } \\
\text { waban atas perta- } \\
\text { nyaan dengan } \\
\text { jelas dan memu- } \\
\text { askan. } \\
\text { Mewakili kepen- } \\
\text { tingan masyarakat }\end{array}$ \\
\hline
\end{tabular}

Tabel 4

Signifikasi Identitas dan Kekuasaan Partisipan

gali informasi melalui narasumber dengan strategi pertanyaan yang telah disiapkan. Adapun narasumber selaku sumber informasi yang diwawancarai juga dianggap memiliki kekuasaan sebagai pembawa informasi yang dapat 'dipercaya' kebenarannya.

Signifikasi identitas adalah personalitas partisipan yang didesain oleh media untuk hadir membawakan perannya, dalam hal ini peran pembawa acara dan narasumber. Representasi identitas memperlihatkan karakter dan daya tarik partisipan selaku individu yang mempresentasikan dirinya melalui ekspresi wajah dan gerakan tangan selama tayangan berlangsung. Adapun makna kekuasaan merepresentasikan tugas dan tanggungjawab yang harus dipenuhi oleh partisipan untuk membangun suasana perbincangan yang dapat memenuhi kebutuhan penonton. Representasi kekuasaan juga dapat dipresentasikan melalui kode- kode visual seperti gesture dan postur.

Dari segi ruang yang menjadi latar, program Talk show 'mata najwa' episode tanggal 28 November 2012 ini menampilkan latar studio tanpa penonton dengan desain ruang diskusi dan wawancara yang ditata berhadapan. Ruang untuk berinteraksi ini memvisualisasikan para partisipan, yaitu Najwa Shihab selaku pembawa acara dan Rhoma Irama selaku narasumber, masing-masing dalam posisi duduk di atas kursi besar bersandaran, di mana jarak antar keduanya dibatasi oleh meja yang lebar sebagai penanda untuk membatasi gerakan dan memberi jarak di antara partisipan. Meja yang lebar adalah juga sebuah petanda adanya perbedaan peran dari masing-masing partisipan.

Dari segi zona pengambilan gambar saat perbincangan berlangsung, tayangan ini menggunakan tiga sudut pandang kamera. Penggunaan sudut pandang jarak dekat secara bergantian menampilkan wajah Najwa Shihab dan Rhoma masing-masing pada saat berbicara untuk membangun makna keintiman antara penonton dengan pembawa acara dan narasumber. Kamera jarak dekat membantu penonton untuk dapat melihat ekspresi wajah pembawa acara dan narasumber.

Kemudian tayangan ini juga melakukan pergerakan kamera jarak sedang untuk menampilkan posisi tubuh sebagian dari kedua partisipan agar penonton dapat melihat hubungan personal di antara Najwa Shihab selaku pewawancara dengan Rhoma Irama selaku orang yang diwawancarai. Visualisasi kedua partisipan pada layar membantu penonton untuk melihat ekspresi dan gerakan tangan keduanya yang dilakukan secara bersamaan saat perbincangan sedang berlangsung. Sudut pandang jarak sedang ini juga dapat memperlihatkan representasi kekuasaan masing-masing partisipan, di mana kedua partisipan melakukan kontak mata dan memperlihatkan posisi tubuhnya saat berbincang. 
Selanjutnya penggunaan sudut pandang kamera jarak penuh dan jarak jauh sesekali ditampilkan untuk menghadirkan latar ruang perbincangan yang mendukung penampilan partisipan secara keseluruhan, sehingga tervisualisasi konteks wilayah kedua partisipan dalam menampilkan identitas dan kekuasaannya. Secara garis beras, rincian sudut pandang kamera yang digunakan pada episode ini dapat dirumuskan dalam tabel 5 .

Makna representasional yang dihasilkan melalui presentasi bahasa tubuh partisipan dalam representasi gambar menunjukkan masing-masing partisipan memposisikan dirinya sesuai dengan jarak yang telah dibatasi oleh meja, di mana kedua partisipan tidak memungkinkan untuk melakukan kontak fisik dalam posisi duduk, kecuali sebatas bersalaman. Posisi duduk dalam ruang yang dibatasi ini adalah sebuah konstruksi untuk menghindari dominasi partisipan satu dengan lainnya. Adapun untuk menciptakan hubungan yang lebih personal, baik pembawa acara maupun narasumber samasama mencondongkan tubuhnya ke depan dengan bagian atas perut merapat ke meja pembatas. Makna representasional yang dipresentasikan dalam visualisasi gambar memperlihatkan bahwa posisi tubuh kedua partisipan sama-sama mencoba memperpendek jarak tatapan sambil tetap membatasi diri dari dominasi lawan bicaranya.

Dalam menemukan makna interaksi melalui presentasi bahasa tubuh antara pembawa acara dan narasumber, jarak tatapan menjadi penting. Semakin dekat jarak pandang yang memungkinkan kedua partisipan memandang lebih lama saat berkomunikasi, maka satu sama lain akan terlihat berupaya memperoleh kekuasaan, khususnya menguasai perbincangan melalui kemampuan investigasi bagi Najwa Shihab dan kemampuan menjawab bagi Rhoma Irama. Najwa Shihab selaku pembawa acara dan pewawancara terlihat lebih mencondongkan tubuhnya ke depan, sedangkan Rhoma Irama sebagai narasumber mempertahankan

\begin{tabular}{|c|l|l|}
\hline Pergerakan Kamera & \multicolumn{1}{c|}{ Makna } \\
\hline Jarak dekat & $\begin{array}{l}\text { Membangun makna keintiman antara penonton de- } \\
\text { ngan pembawa acara dan narasumber. Kamera jarak } \\
\text { dekat membantu penonton untuk dapat melihat } \\
\text { ekspresi wajah pembawa acara dan narasumber se- } \\
\text { cara lebih dekat. }\end{array}$ \\
Jarak sedang & $\begin{array}{l}\text { Membangun hubungan personal di antara Najwa } \\
\text { Shihab selaku pewawancara dengan Rhoma Irama } \\
\text { selaku terwawancara. Menampilkan ekspresi wajah } \\
\text { dan gerakan tangan keduanya secara bersamaan saat } \\
\text { perbincangan sedang berlangsung, sekaligus mere- } \\
\text { presentasikan kekuasaan partisipan melalui tatapan } \\
\text { dan posisi tubuh saat berbincang. }\end{array}$ \\
Jarak penuh dan \\
jarak jauh
\end{tabular}

Tabel 5

Pergerakan Kamera dalam Talk show 'mata najwa' 


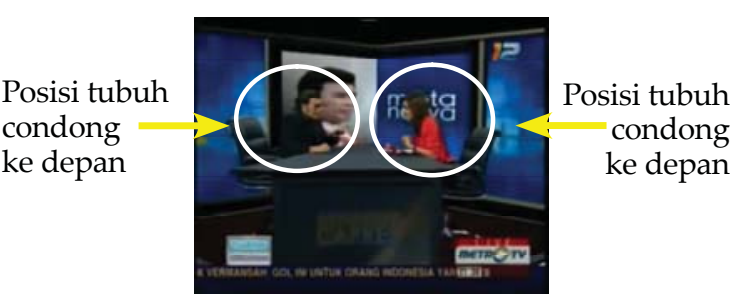

Gambar 4

Presentasi Posisi Tubuh Partisipan

Sumber: Daniel As-Huri, 2 Desember 2012, 'mata najwa' - Rhoma Irama Mendadak Capres, http:// www.youtube.com/watch? $v=P C w H d P R 118 Q$, diakses 5 November 2013.

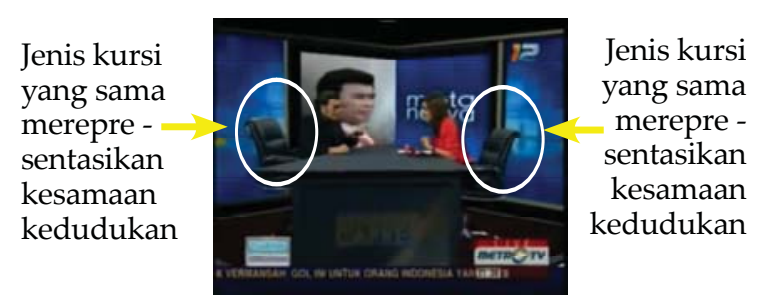

Gambar 5

Elemen-Elemen Visual Pendukung Makna Sumber: Daniel As-Huri, 2 Desember 2012,'mata najwa' - Rhoma Irama Mendadak Capres, http:// www.youtube.com/watch?v=PCwHdPRll8Q, diakses 5 November 2013.

\begin{tabular}{|c|c|c|}
\hline Tanda & Presentasi Bahasa Tubuh & Makna \\
\hline Representasi & $\begin{array}{l}\text { Masing-masing partisipan memposisikan } \\
\text { diri sesuai dengan jarak yang telah diba- } \\
\text { tasi oleh meja, di mana pembawa acara dan } \\
\text { narasumber tidak memungkinkan untuk } \\
\text { melakukan kontak fisik dalam posisi duduk, } \\
\text { kecuali sebatas bersalaman. }\end{array}$ & $\begin{array}{l}\text { Posisi duduk pembawa acara dan narasumber } \\
\text { dalam ruang yang dibatasi oleh meja sebagai } \\
\text { jarak adalah sebuah konstruksi untuk meng- } \\
\text { hindari dominasi kekuasaan partisipan satu } \\
\text { dengan lainnya. }\end{array}$ \\
\hline Interaksi & $\begin{array}{l}\text { Posisi duduk Najwa Shihab selaku pembawa } \\
\text { acara lebih condong ke depan. Sedangkan } \\
\text { posisi duduk Rhoma Irama sebagai nara- } \\
\text { sumber tidak melebihi dari batas pinggiran } \\
\text { meja. Baik Najwa Shihab maupun Rhoma } \\
\text { Irama mempresentasikan identitas dan } \\
\text { kekuasaannya melalui gerakan-gerakan ta- } \\
\text { ngan, seperti mengangkat tangan, menunjuk } \\
\text { dan membuka tangan. }\end{array}$ & $\begin{array}{l}\text { Jarak tatapan dalam berinterasi menjadi pen- } \\
\text { ting. Semakin dekat jarak kontak mata yang } \\
\text { memungkinkan kedua partisipan meman- } \\
\text { dang lebih lama saat berbincang, maka satu } \\
\text { sama lain dapat saling berupakan mem- } \\
\text { peroleh kekuasaan, khususnya kekuasaan } \\
\text { dalam menginvestigasi bagi Najwa Shihab } \\
\text { dan kekuasaan dalam menjawab pertanyaan } \\
\text { bagi Rhoma Irama. }\end{array}$ \\
\hline Komposisi & $\begin{array}{l}\text { Najwa Shihab dan Rhoma irama sama-sama } \\
\text { duduk di atas jenis kursi yang sama. }\end{array}$ & $\begin{array}{l}\text { Tidak adanya perbedaan status di antara par- } \\
\text { tisipan, di mana partisipan yang satu tidak } \\
\text { memiliki kedudukan yang lebih tinggi dari } \\
\text { partisipan lainnya. }\end{array}$ \\
\hline
\end{tabular}

Tabel 6

Pembacaan Bahasa Tubuh Menurut Konteks Orang, Tempat, dan Tampilan Benda

posisi duduk dan tubuhnya tidak lebih dari batas pinggiran meja. Baik Najwa Shihab maupun Rhoma Irama mempresentasikan identitas dan kekuasaannya melalui gerakangerakan tangan, seperti mengangkat tangan, menunjuk dan membuka tangan.

Selanjutnya komposisi penempatan elemen-elemen visual pendukung yang menghubungkan makna representasional dan makna interaksi gambar dengan gambar lainnya dipresentasikan melalui pengambilan gambar jarak penuh dan jarak jauh. Presentasi jenis kursi yang sama sebagai elemen visual pendukung merepresentasikan tidak adanya perbedaan status di antara partisipan, di mana partisipan yang satu tidak memiliki kedudukan yang lebih tinggi dari partisipan lainnya.

Selama perbincangan, presentasi fasial dan presentasi postural yang ditampilkan para partisipan berdasarkan pengambilan gambar oleh kamera dapat dijabarkan sebagai berikut:

\section{Presentasi Fasial}

Bahasa tubuh ekspresi wajah dan orientasi wajah pembawa acara (lihat gambar 6). Bahasa tubuh ekspresi wajah dan orientasi wajah narasumber (lihat gambar 7).

Pada presentasi pembawa acara, penonton telah memiliki referensi tentang pro- 

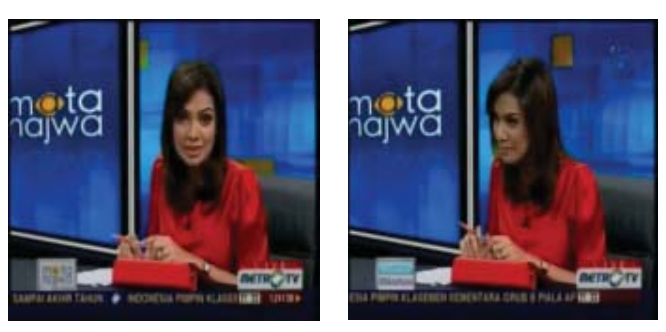

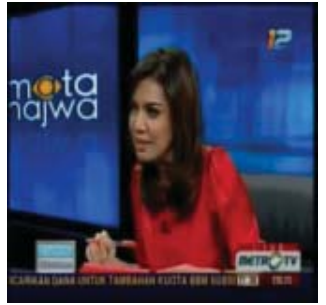

Gambar 6

Rangkaian Orientasi Wajah Pembawa Acara

Sumber Gambar: Daniel As-Huri, 2 Desember 2012, "mata najwa"'- Rhoma Irama Mendadak Capres, http://www.youtube.com/watch?v=PCwHdPRll8Q, diakses 5 November 2013.
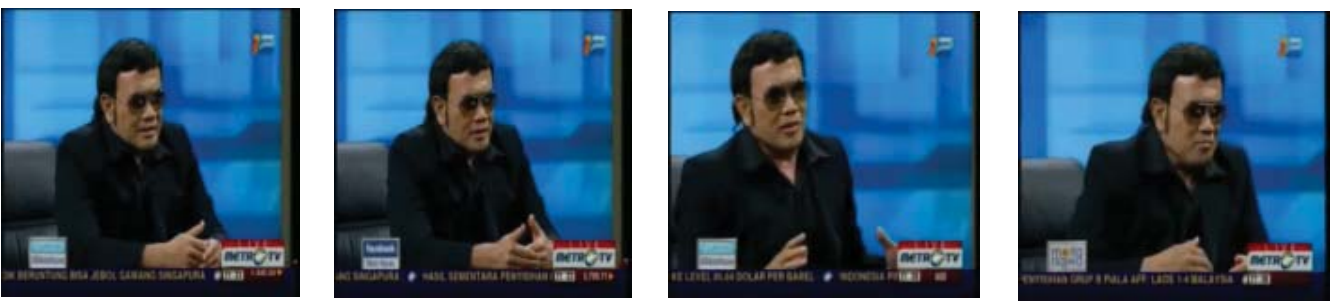

Gambar 7

Rangkaian Orientasi Wajah Narasumber

Sumber Gambar: Daniel As-Huri, 2 Desember 2012, "mata najwa"- Rhoma Irama Mendadak Capres, http://www.youtube.com/watch?v=PCwHdPRll8Q, diakses 5 November 2013.

fesionalitas pembawa acara Najwa Shihab sebagai jurnalis senior yang berprestasi. Pada presentasi narasumber, sosok yang ditampilkan umumnya dipilih dari kalangan pengamat, wakil pemerintah, dan wakil lembaga masyarakat. Narasumber dipilih dari tokoh-tokoh publik yang dianggap dapat mewakili kepentingan masyarakat. Rhoma Irama, penyanyi dangdut yang mencalonkan diri sebagai calon presiden 2014, dianggap sebagai tokoh publik kontroversial yang dapat mewakili suara kelompok masyarakat tertentu.

Presentasi fasial partisipan selama berbincang dapat dilihat melalui pengambilan gambar jarak sedang dan jarak dekat terhadap ekpresi wajah dan orientasi wajah. Dalam pembukaan acara, Najwa Shihab menampilkan dirinya dengan ekspresi wajah penuh senyum sebagai konstruksi daya tariknya untuk menyajikan acara yang menarik perhatian. Akan tetapi, saat perbincangan dengan narasumber dimulai, pusat daya tarik fasialnya diorientasikan kepada bahasa matanya yang menatap tajam ke arah narasumber, baik saat bertanya maupun saat mendengarkan jawaban. Najwa Shihab sebagai pembawa acara memang dituntut untuk menyajikan fakta-fakta kebenaran tentang informasi, di mana kebenaran tersebut diperkuat dengan keterangan dari narasumber. Oleh karena itu, makna representasional yang dipresentasikan secara fasial oleh pembawa acara memperlihatkan bahasa mata sebagai ekspresi wajah untuk menciptakan kendali atas suasana perbincangan. Kontak mata yang lama menunjukkan bahwa pembawa acara menunjukkan kekuasaannya sebagai investigator yang memiliki kapabilitas. Identitas tatapan mata ini menjadi ciri khas pembawa acara yang secara metaforis diterjemahkan melalui nama program 'mata najwa' untuk mewakili kedalaman informasi penyajiannya.

Interaksi yang muncul dari relasi kontak mata yang lama oleh pembawa acara terbangun melalui pengambilan gambar jarak dekat secara bergantian ke visualisasi wajah narasumber. Ekspresi wajah Rhoma Irama terkesan tanpa senyum di mana orientasi 
tatapan matanya tidak terlalu dapat dilihat karena penggunaan kacamata hitam. Visualisasi ini memperlihatkan adanya bahasa tubuh dari narasumber untuk melindungi diri dan tidak sepenuhnya dapat 'dikuasai' oleh pembawa acara. Dalam hal ini, aksesori kacamata hitam yang digunakan narasumber dapat dianggap sebagai elemen visual pendukung yang 'melindungi' narasumber dari dominasi tatapan pembawa acara.

Adapun investigasi yang dilakukan pembawa acara didukung oleh elemen visual perangkat teknologi notebook yang berisi referensi informasi tentang isu-isu yang melibatkan sang tokoh. Relasi dari keseluruhan visualisasi presentasi fasial tersebut menunjukkan makna identitas diri dari pembawa acara sebagai penyaji informasi yang mewakili keingintahuan penonton, dan identitas diri dari narasumber sebagai pembawa informasi yang kebenaran informasinya dapat mewakili kepentingan kelompok masyarakat tertentu.

\section{Presentasi Postural}

Bahasa tubuh gerakan tangan dan perilaku khas pembawa acara (lihat gambar 8). Bahasa tubuh gerakan tangan dan perilaku khas narasumber (lihat gambar 9).

Presentasi postural partisipan selama berbincang dapat dilihat melalui pengambilan gambar jarak sedang dan jarak dekat terhadap gerakan tangan dan perilaku khas yang spesifik dari partisipan. Dengan posisi tubuh masing-masing partisipan yang agak condong ke depan merapat ke arah meja, maka tangan dan lengan keduanya diletakkan di atas meja. Selama berbincang, pembawa acara memperlihatkan gerakan kedua telapak tangan yang saling merapat, kadangkadang terbuka, di mana di antara sela-sela jarinya terselip sebuah pena. Gerakan kedua telapak tangan ini menunjukkan bahasa tubuh pembawa acara untuk menggali informasi dari narasumber.

Selain itu, pembawa acara juga menunjukkan perilaku khas dari gerakan tangan berulang, yaitu memegang dan menopang dagu dengan jari-jarinya. Gaya gerakan ini dapat bermakna keseriusan dan keingintahuan yang tinggi untuk mendengarkan jawaban dari narasumber. Pembawa acara dalam hal ini merepresentasikan diri sebagai investigator yang mewakili keingintahuan masyarakat tentang 'kebenaran' informasi.

Adapun interaksi yang terbangun melalui presentasi postural dari narasumber ditunjukkan melalui gerakan kedua tangan yang merapat, kadang kedua tangan terbuka, dan sesekali sebelah tangannya menunjuk ke depan. Gerakan tangan ini merupakan upaya dari narasumber untuk

\begin{tabular}{|c|c|c|}
\hline Presentasi Fasial & Identitas & Makna \\
\hline $\begin{array}{l}\text { Ekspresi wajah } \\
\text { Najwa Shihab }\end{array}$ & Sering tersenyum & Sikap terbuka \\
\hline $\begin{array}{l}\text { Orientasi tatapan } \\
\text { mata Najwa } \\
\text { Shihab }\end{array}$ & $\begin{array}{l}\text { Sering menatap dan melakukan } \\
\text { kontak mata yang lama }\end{array}$ & $\begin{array}{l}\text { Melalui kontak mata, pembawa acara menun- } \\
\text { jukkan kekuasaannya sebagai investigator. } \\
\text { Identitas tatapan mata ini menjadi ciri khas } \\
\text { pembawa acara }\end{array}$ \\
\hline $\begin{array}{l}\text { Ekspresi wajah } \\
\text { Rhoma Irama }\end{array}$ & Tanpa senyum & Sikap menahan/menutup diri \\
\hline $\begin{array}{l}\text { Orientasi tatap- } \\
\text { an mata Rhoma } \\
\text { Irama }\end{array}$ & $\begin{array}{l}\text { Kontak mata yang terlindung } \\
\text { kacamata }\end{array}$ & $\begin{array}{l}\text { Narasumber tidak sepenuhnya dapat 'dikua- } \\
\text { sai' oleh pembawa acara karena adanya elemen } \\
\text { visual kacamata hitam. Narasumber terhindar } \\
\text { dari dominasi tatapan pembawa acara. }\end{array}$ \\
\hline
\end{tabular}



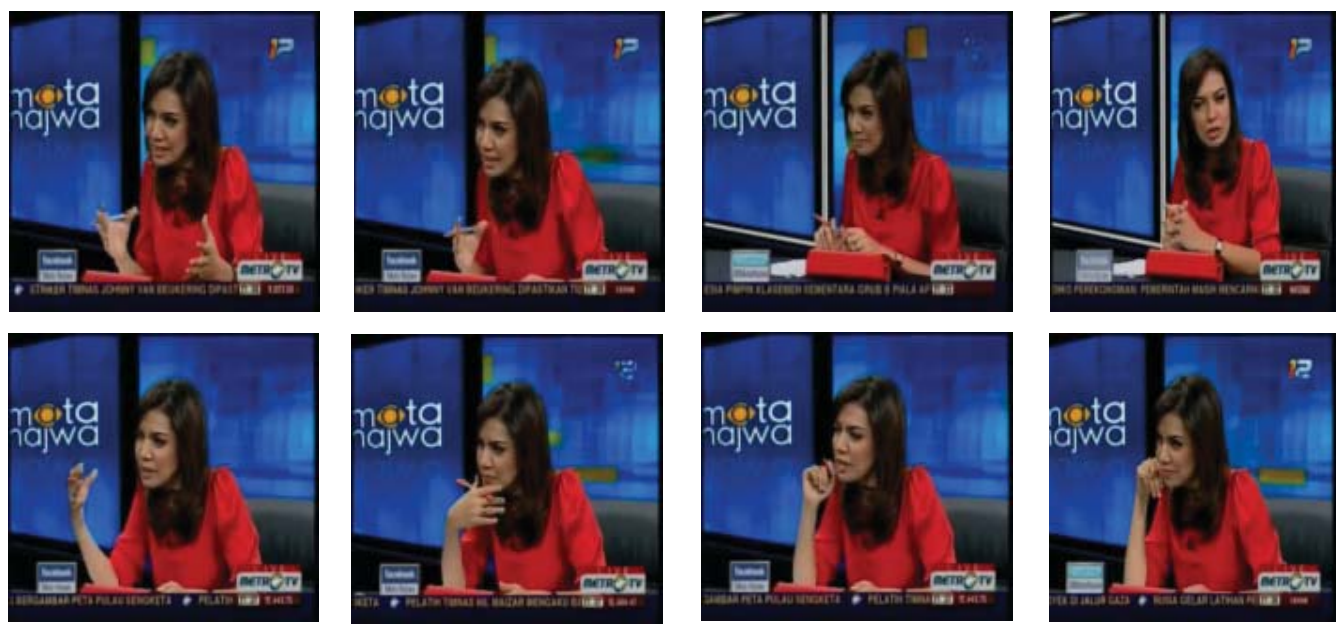

Gambar 8

Rangkaian Gerakan Tangan dan Perilaku Khas Pembawa Acara

Sumber Gambar: Daniel As-Huri, 2 Desember 2012, "mata najwa" - Rhoma Irama Mendadak Capres, http://www.youtube.com/watch?v=PCwHdPRll8Q, diakses 5 November 2013.
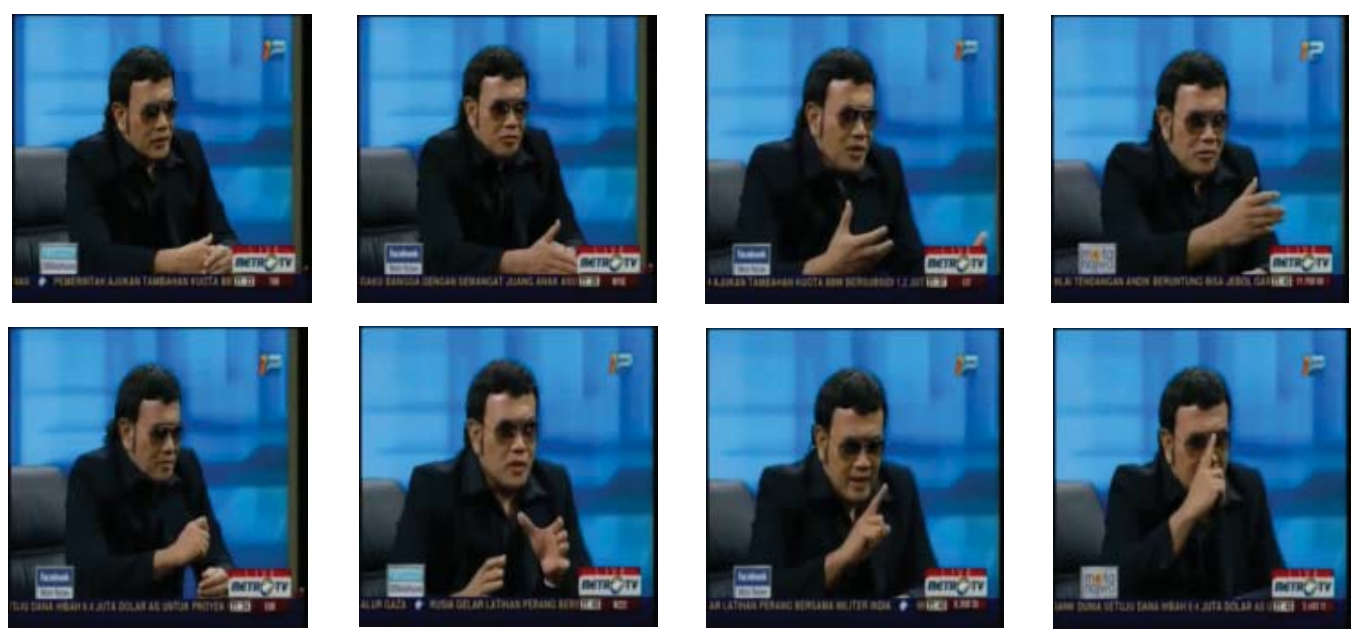

Gambar 9

Rangkaian Gerakan Tangan dan Perilaku Khas Narasumber

Sumber Gambar: Daniel As-Huri, 2 Desember 2012, 'mata najwa' - Rhoma Irama Mendadak Capres, http://www.youtube.com/watch?v=PCwHdPRl18Q, diakses 5 November 2013.

meyakinkan pembawa acara dan penonton bahwa informasi yang disampaikannya dapat 'dipercaya'.

Baik pembawa acara maupun narasumber sama-sama mempresentasikan gesture yang bersifat konotatif, yaitu suatu gerakan tangan untuk mengkomunikasikan citra tertentu menurut asosiasi yang berlaku.

Adapun perilaku khas yang ditampilkan narasumber untuk menunjukkan kekuasaannya terhadap informasi yang dimilikinya dapat dilihat secara berulang melalui gerakan mengarahkan tangan ke depan sambil menunjukkan jari. Gerakan menunjuk dapat dimaknai sebagai penegasan jawaban untuk mendominasi suasana perbincangan. Dalam hal ini, upaya narasumber untuk membatasi eksistensi pembawa acara selaku investigator tidak didukung oleh ekspresi wajahnya, terutama melalui kontak mata karena adanya elemen visual kacamata hitam yang menutupi orientasi tatapan. 


\begin{tabular}{|c|c|c|}
\hline $\begin{array}{c}\text { Presentasi } \\
\text { Postural }\end{array}$ & Identitas & Makna \\
\hline Gerakan tangan & Membuka kedua telapak tangan & Menggali informasi \\
\hline \multirow[t]{4}{*}{ Najwa Shihab } & Menggerakkan sebelah tangan & Mempertanyakan jawaban \\
\hline & Merapatkan kedua jari-jari tangan & Menunggu jawaban \\
\hline & Memegang pulpen & Menegaskan pertanyaan \\
\hline & Memegang notebook & Mengkonfirmasi jawaban \\
\hline $\begin{array}{l}\text { Perilaku khas } \\
\text { Najwa Shihab }\end{array}$ & $\begin{array}{l}\text { Menopang, memegang dagu } \\
\text { dengan jari/punggung tangan }\end{array}$ & $\begin{array}{l}\text { Keseriusan dan penuh keinginta- } \\
\text { huan }\end{array}$ \\
\hline Gerakan tangan & Merapatkan kedua jari-jari tangan & Menunggu pertanyaan \\
\hline \multirow[t]{4}{*}{ Rhoma Irama } & $\begin{array}{l}\text { Menggerakkan sebelah tangan ke } \\
\text { depan }\end{array}$ & Membatasi jawaban \\
\hline & Membuka kedua telapak tangan & Memperjelas jawaban \\
\hline & Mengepalkan tangan & Meyakinkan jawaban \\
\hline & Menunjukkan tangan ke depan & Menegaskan jawaban \\
\hline $\begin{array}{l}\text { Perilaku Khas } \\
\text { Rhoma Irama }\end{array}$ & $\begin{array}{l}\text { Membetulkan kacamata dengan } \\
\text { jari telunjuknya }\end{array}$ & Berpikir sebelum menjawab \\
\hline
\end{tabular}

Tabel 8

Makna Bahasa Tubuh Menurut Presentasi Postural Partisipan

Sebaliknya pewawancara mempertahankan kekuasaannya untuk menggali, menegaskan, dan mengkonfirmasi jawaban melalui elemen visual notebook sebagai perangkat investigasi wawancara yang akuntabel, tercatat, dan mengandung kebenaran.

Dalam Talk show ini, masing-masing partisipan membentuk identitas individu dan mempresentasikan 'kekuasaan' nya melalui bahasa tubuh, khususnya melalui ekspresi wajah, gerakan tangan, dan posisi tubuhnya. Melihat tayangan Talk show tersebut, secara tidak langsung penonton juga diajak untuk melihat kekuatan visual bahasa tubuh partisipan melalui kemampuan pembawa acara dalam mengajukan pertanyaan dan kemampuan narasumber untuk menjawab pertanyaan dengan dukungan bahasa tubuhnya. Bahasa tubuh partisipan membantu mempengaruhi persepsi penonton terhadap citra partisipan di dalam layar, dan secara tidak sadar mempengaruhi opininya berdasarkan informasi visual yang diterimanya. Acara Talk show semacam ini didesain untuk mengajak penonton melihat dan merasakan kekuatan visual partisipan berdasarkan identitas dan kekuasaan kolektif yang hadir secara bersamaan baik verbal maupun nonverbal, sehingga membangun sebuah tontonan perbincangan sosial politik yang menarik.

\section{PENUTUP}

Studi ini menunjukkan bahwa bahasa tubuh melalui presentasi fasial dan postural dapat menjadi penanda yang mengandung makna. Representasi visual menyampaikan makna bahwa Najwa Shihab selaku pembawa acara adalah pewawancara yang memiliki identitas individual melalui ekspresi tatapan mata, serta mampu membangun suasana perbincangan melalui gaya investigasi melalui gerakan tangannya yang khas. Sedangkan Rhoma Irama selaku narasumber mempresentasikan identitas dirinya melalui gerakan tangan dan perilaku khasnya untuk merepresentasikan kekuasaannya sebagai pembawa informasi yang dapat dipercaya. 
Dalam konteks wacana visual, studi ini dapat menjadi model pembahasan ilmiah bahwa kekuatan visual sebuah tayangan Talk show tidak terlepas dari presentasi peran dan penampilan pembawa acara dan narasumber secara verbal dan nonverbal. Pembacaan teks visual nonverbal terhadap bahasa tubuh partisipan dapat memberikan makna identitas tentang ciri khas partisipan sebagai pembawa acara dan narasumber yang memiliki kemampuan untuk menggali dan menjawab informasi, sesuai dengan kebutuhan penontonnya. Makna kekuasaan yang dipresentasikan melalui kode-kode visual gesture dan postur juga dapat merepresentasikan tugas dan tanggungjawab partisipan sebagai orang-orang yang dianggap dapat mewakili kepentingan media dan masyarakat. Dengan kata lain, desain program Talk show berita memiliki tempat tersendiri di dalam genre tontonan masyarakat, di mana makna representasi visual partisipan yang terbangun melalui bahasa visual nonverbal memiliki kekuatan visual untuk membawa pesan, sekaligus mempengaruhi persepsi penonton.

\section{Daftar Pustaka}

Block, Bruce

2008 The Visual Story, Creating The Visual Structure of Film, TV, and Digital Media, Second Edition. Elsevier and Focal Press.

Burton, Graeme

2011 Membincangkan Televisi, Sebuah Pengantar Kajian Televisi. Yogyakarta: Jalasutra.

Cohen, David

2009 Body language (Bahasa Tubuh), Apa yang Perlu Anda Ketahui. Tangerang: Karisma Publishing.
Danesi, Marcel

2009 Dictionary of Media and Communications. London - New York - Armonk: M.E.Sharpe

Fairclough, Norman

2006 Discourse and Social Change (6th ed.). Cambridge and Malden: Polity Press.

Fiske, John

2007 Cultural and Communication Studies, Sebuah Pengantar Paling Komprehensif. Cetakan ke-4. Yogyakarta: Jalasutra.

Jalaluddin Rakhmat

2008 Psikologi Komunikasi, Cetakan ke-26. Bandung: PT. Remaja Rosdakarya.

Lawrence, Cooper

2009 The Cult of Celebrity, What Our Fascination With The Star Reveals About Us. Guilford, Connecticut: Skirt

Littlejohn, Stephen W.

1996 Theories of Human Communication, Second Edition, Humbolt State University, Belmont California: Wedsworth Publishing Company

Mirzoeff, Nicholas

1999 An Introduction To Visual Culture. New York: Routledge.

Timberg, Bernard M.

2002 Television Talks, A history of The TV Talk show. Austin: The University of Texas Press.

Van Leeuwen, Theo

2005 Introducing Social Semiotics. New York: Routledge.

Winny Gunarti Widya Wardani, Yasraf Amir Piliang, dan Achmad Syarief

2013 Perception Construction To Political I- 
ssues Through Live Interview On Television News. Paper Presentation at The 2013 Annual International Conference on Advances Technology in Telecommunication, Broadcasting, and Satelite (TelSaTech 2013), Jakarta, 2-3 Agustus 2013.

Wundt, Wilhelm

1973 The Language of Gestures. Paris: Mouton
Sumber lain:

Daniel As-Huri, 2 Desember 2012, "mata najwa"'-Rhoma Irama Mendadak Capres, http://www.youtube.com/ watch? $\mathrm{v}=\mathrm{PC}$ HHdPRll8Q, diakses 5 November 2013.

Metro TV, http://www.metrotvnews.com/ read/anchor, diakses 15 Februari 2014 